\title{
School Smartification and Retention of Biology Lesson: Case Study in Iran
}

\author{
Farzaneh Salehipour, Maryam Bohlouli* \\ Department of Humanities, Doroud Branch, Islamic Azad University, Doroud, Iran
}

Email address:

doroud.iau.ir@gmail.com (M. Bohlouli)

${ }^{*}$ Corresponding author

To cite this article:

Farzaneh Salehipour, Maryam Bohlouli. School Smartification and Retention of Biology Lesson: Case Study in Iran. Science Journal of Education. Vol. 5, No. 1, 2017, pp. 1-4. doi: 10.11648/j.sjedu.20170501.11

Received: December 18, 2016; Accepted: January 12, 2017; Published: January 31, 2017

\begin{abstract}
In this paper, the influence of smart schools on retention of biology lesson among first grade high school students of Kermanshah city in Iran is studied in education year 2015-2016. The research method is quasi-experimental with two experiment and control groups. By cluster random sampling, two classes with normal educational system and two classes with smart educational system are selected among first grade high school students of Kermanshah. The sample size included 100 students who are divided into two 50-member experimental and control groups. The independent variable is smart schools and the dependent variable is retention. The content of the eighth chapter of the biology book is taught to both groups in normal and smart methods. The applied tool is a researcher-designed retention test that is performed in two pretest and posttest retention stages in two groups. First, no significant difference is seen in the levels of preliminary knowledge of the students in two groups. After the experiment, a posttest is condycted to evaluate retention level in both groups. The average score of the experiment group is bigger than the average score of the control group. The independent $t$-test is used to examine the research hypothesis. This test is calculated with $95 \%$ confidence, which indicates a significance difference between the students' retention process in biology and its implication in teaching and retention of biology.
\end{abstract}

Keywords: Smart Education, Normal Education, Retention, Biology

\section{Introduction}

Technology is the most important criterion of development, particularly in the modern world; and education is a tool to become familiar and have access to new technologies [1], [2], [3]. Using technology in education will reduce education costs, save time, increase learning opportunities, increase educational success, and increase the possibility of quick access to information [4]. Smart schools are new approach in education that will make fundamental changes in the process of teaching and learning by combining IT and learning programs [5]. Accordingly, it is necessary for the education programs to be organized in line with these changes and with respect to the needs of society [6].

Smartification causes retention from other sources to be a tool for learning progress in many subjects. It can also develop students' innovative abilities, encourage them to be responsible for their own learning and motivate them to have a mutual interaction with a bigger community [7]. On the other hand, retention of discussions in biology is fundamental and necessary, and all scientists and policy-makers of technology believe that biology is the most strategic knowledge and technology in which if a country makes progress.

The researchers' investigations have shown that explaining discussions to others, reviewing and reading them loudly help profound learning [8]. By studying Recency Model, the researchers concluded that fast learners forget faster as well and slow learners forget slower [9]. What seems highly important is the manner of studying this lesson and understanding the concepts and key points of the book. Therefore, by this research, the influence of the role of smart schools on the retention in biology will be studied. There is a 
process in retention called image stabilization in which visible information or a part of it that is understood by an image, is learned better and more than other contents; therefore, its retention will be increased [10].

Lovel Monky [11] showed that the speed of using the methods of virtual learning is doubled and our children are floated in an unreal world full of symbols more than ever. Collis [12] showed that the main determining factor of efficiency in using IT in class and education progress is teacher's skill in using IT and having a positive view about it so that retention seems to be more comprehensive and real. In a study done by Mayer [13], it is illustrated that presenting information via multimedia method will motivate students to do activities such as selecting, organizing, and integrating visual and auditory information and improve retention and learning and, consequently, their education progress.

Atkinson [10] compared learning in a traditional situation and retention by computer and studied its relationship with gender and cognitive style. His report indicates that people with verbal cognitive style have the most positive view and best performance in retention by computer. In a research, Urdan et al. [14] discussed the advantages of electronic learning the results of which showed that in this kind of education, stable high-quality content is created and education costs would reduce 50 to 70 percent.

Wang [15] made a comparison between electronic learning and normal learning in class. He showed that retention in electronic learning is better than retention in normal learning. Hamzah et al. [16], also, announced that students have a positive view regarding changes in smart schools compared to public schools, and finally, they more advance in education.

\section{Materials and Methods}

In this research, quasi-experimental method with pretest and posttest and follow up team are used and implemented in smart and normal high schools in Kermanshah. According to statistics of education office in Kermanshah, the statistical population in educational year 2015-2016 included 12123 students. Cluster random sampling is used in a way that two girls' schools and two boy's schools are selected from state and smart schools randomly. Sample size included 100 students out of which 50 students were put in the experiment group and 50 students were put in the control group.

First, all students are tested by one pretest (20 questions with 20 scores) that included 4 true/false questions, four multiple choice questions, four fill in questions, and four long-answer questions. The allocated time to answer the questions was 90 minutes. Then eighth chapter of biology book is taught to students within eight 90 -minute sessions. The same happened for the control group. To prevent intervention of confounding variables, pretest and posttest are done in completely same situations.

The content of education program in smart schools include eighth chapter of the biology book in which both student and teacher present producing electronic content and lesson as $\mathrm{CD}$ using technology tools. Education is not limited to teacher, rather, teaching and learning is fully interactive, and students have a main role in learning scientific discussions. By databases and software programs, the teachers revise and change present courses. The content of education program in public schools includes eighth chapter of biology and health lesson that is taught by teacher traditionally using whiteboard.

Research-made retention test: the test included 20 questions of eighth chapter of biology book with 20 points that included 4 true/false questions, four multiple choice questions, four fill in questions, and four long-answer questions, and it is performed on both experiment and control groups as retention pretest and posttest. All questions had high validity and the score of each question is bigger than 1.5. Using Spearman correlation coefficient Editors' reliability coefficient in this research between the judgments of two graders is obtained as 0.98 .

\section{Result}

Kolmogorov-Smirnov test shows that statistical data have a normal distribution $(p>0.05)$. The results are shown in Table 1. Therefore, parametrical test can be used for retention analysis.

Table 1. Kolmogorov-Smirnov test for normality of data distribution.

\begin{tabular}{lll}
\hline & & retention \\
\hline $\mathrm{N}$ & & 100 \\
Normal Parameters & Mean & 9.3100 \\
& Std. Deviation & 3.90110 \\
\multirow{2}{*}{ Most Extreme Differences } & Absolute & .055 \\
& Positive & .055 \\
Test Statistic & Negative & -.041 \\
Asymp. Sig. (2-tailed) & & .055 \\
\hline
\end{tabular}

After doing experiment and implementation of tests in order to examine hypotheses and analyze statistical data of both groups, parametric independent T-test is applied using SPSS software. The results are shown in Tables 2 and 3.

Table 2. Mean and standard deviation in two experiment and control groups.

\begin{tabular}{llllll}
\hline & group & N & Mean & Std. Deviation \\
\hline \multirow{2}{*}{ retention } & control & 50 & 7.2350 & 3.01375 & Std. Error Mean \\
& experiment & 50 & 11.3850 & 3.58861 & .42621 \\
\hline
\end{tabular}


Table 3. Results of independent t-test on data

\begin{tabular}{|c|c|c|c|c|c|c|c|c|c|c|}
\hline & & \multicolumn{2}{|c|}{$\begin{array}{l}\text { Levene's Test } \\
\text { for Equality of } \\
\text { Variances }\end{array}$} & \multicolumn{7}{|c|}{ t-test for Equality of Means } \\
\hline & & \multirow[t]{2}{*}{$\mathbf{F}$} & \multirow[t]{2}{*}{ Sig. } & \multirow[t]{2}{*}{$\mathbf{t}$} & \multirow[t]{2}{*}{ df } & \multirow{2}{*}{$\begin{array}{l}\text { Sig. (2- } \\
\text { tailed) }\end{array}$} & \multirow{2}{*}{$\begin{array}{l}\text { Mean } \\
\text { Difference }\end{array}$} & \multirow{2}{*}{$\begin{array}{l}\text { Std. Error } \\
\text { Difference }\end{array}$} & \multicolumn{2}{|c|}{$\begin{array}{l}95 \% \text { Confidence Interval of the } \\
\text { Difference }\end{array}$} \\
\hline & & & & & & & & & Lower & Upper \\
\hline retention & $\begin{array}{l}\text { Equal variances } \\
\text { assumed }\end{array}$ & .817 & .368 & -6.262 & 98 & .000 & -4.15000 & .66273 & -5.46517 & -2.83483 \\
\hline
\end{tabular}

Table 3 shows that with respect to $F=0.817$ and $p<0.05$, there is a significant difference between two experiment and control groups' score difference between retention pretest and posttest.

\section{Discussion}

By increasing motivation, students' attempts to more retention, and consequently, their scores will be more and higher. Increasing motivation and scores would lead to students' positive view on themselves and their abilities, and finally would lead to positive self-concept. The results, also, show that students in smart schools are more independent than students in public schools. Graphical images, various sounds, and educational movies could make environment attractive for retention and students learn lessons deeper. By making students active in the process of learning in smart schools, retention increases, and in addition to using auditory sense, students' visual sense and cognitive activity would be motivated. In smart schools, learners have a high selfregulation and, therefore, they do their activities actively, and search for new information and sources.

The results of the research are in line with the studies of [10], [11], [12], [13], [14], and [15]. To explain this result, it can be said that new computer and multimedia could change the retention environment, make it attractive, attract students to the process of retention, add reinforcing stimuli to education and retention process in order to improve education quality, and finally increase learners' motivation to retention of lessons.

\section{Conclusion}

This research aims to study the influence of smart schools on retention of biology lesson in first grade of high school in Kermanshah in Iran. The difference of pretest and posttest scores for both control and experiment groups indicate that there is a significant difference between the groups. The results show that smart schools increase students' retention considerably. The following suggestions are presented for further research:

- Regarding the influence of smart schools on students' retention, it is suggested that teachers use contentmaking software in other subjects to increase retention of that lesson.

- To develop smart schools due to their positive influence on retention of lessons

- To make teachers familiar with computer teaching, it is suggested to consider appropriate training courses for them.

- Teaching using electronic learning tools to students and mastering new software

\section{References}

[1] Devlin, M. and McKay, J., 2016. Teaching students using technology: Facilitating success for students from low socioeconomic status backgrounds in Australian universities. Australasian Journal of Educational Technology, 32 (1).

[2] Nowroozi, M.; Zandi, F.; Moosavi Madani, F.; 2007. Ranking the Methods of IT Application in Retention-LearningEducating Process in School, quarterly journal of Educational Technology, 26: 10-34.

[3] Leavitt, P., 2016. The Effects of Student Social Class on Learning in Computer-Mediated Versus Face-to-Face Settings.

[4] Rahimi, M.; Yadollahi, S. (2011). High School Students' Anxiety and Its Relation to Using Computer and Owning Personal Computer, proceedings of the fourth conference in ELearning, Tehran: University of Science and Industry, September $18^{\text {th }}$, p. $1-8$.

[5] Pillay V. (1997). Comparing the rate of learning in the students of normal and smart schools, American Library Association.

[6] Gultekina, M. (2010). Teachers and students' views on the teaching and learning process of the social studies course. Procedia social and behavioral sciences, 2 (2): 2744-2749.

[7] Ahmadi, M.; Fallah, V; and Mirzakhani, S. (2011). Comparison of the Influence.

[8] Chen, Y. H. and Chen, P. J., 2015. MOOC study group: Facilitation strategies, influential factors, and student perceived gains. Computers \& Education, 86, pp. 55-70.

[9] Sikstrom, S. and Jaber, M. Y. (2002). The Power Integration Diffusion (PID) Model for production breaks. Journal of Experimental Psychology: Applied 8, 118-126.

[10] Atkinson, S. 2004. Using Information and communication Technology in a modular Distance Learning Course, European journal of Engineering Education, Vol 3, NO, PP: 23-45.

[11] Monky, L. (2009). Understanding Virtual Organizations, Information systems Control Journal, Vol. 6. 
[12] Collis V., Computer education for teachers, New York: McGrew-Hill, 2007.

[13] Mayer R., The promise of educational psychology, prentice hall, 2004.

[14] Urdan T. and Weggen C., E-Learning: Exploringa New Frontier, 2003.
[15] Wang, S. (2000). Multimedia and some of its technical issues. nternational Journal of instructional Media.

[16] Hamzah, M. and Embi, M. (2010). Ict and diversity in learners a Hitude on smart school initiative, Available at: http://www.sciencedirect.com 